Miller, J.H. ; Newton, M. 1983. Nutrient loss from disturbed forest watersheds in Oregon's Coast Range. Agro-Ecosystems 8: 153-167.

Agro-Ecosystems, 8 (1983) 153-167

Elsevier Scientific Publishing Company, Amsterdam -Printed in The Netherlands

\title{
NUTRIENT LOSS FROM DISTURBED FOREST WATERSHEDS IN OREGON'S COAST RANGE*
}

JAMES H. MILLER** and MICHAEL NEWTON

Forest Research Laboratory, School of Forestry, Oregon State University, Corvallis, OR 97331 (U.S.A.)

(Accepted 20 January 1982)

\section{ABSTRACT}

Miller, J.H. and Newton, M., 1983. Nutrient loss from disturbed forest watersheds in Oregon's Coast Range. Agro-Ecosystems, 8: 153-167.

Dissolved nutrients were monitored bi-weekly in stream water draining 14 upland watersheds in Oregon's Coast Range after spraying with 2,4.5-T + 2,4-D, clearclit harvesting and slash burning. Anion generation and leaching were primarily studied. The nitrate concentrations fell and the bicarbonate concentrations rose during summer low-flows from treated watersheds without detectable increases in loss of macronutrients $(\mathrm{N}, \mathrm{Ca}, \mathrm{Mg}, \mathrm{K}$, $\mathrm{Na}$ ). The stream water concentrations of bicarbonate (the most prevalent anion) related to watershed orientation and the degree of devegetation. Nitrate concentrations appeared to be correlated positively with watershed drainage rates. Studies with incubated soils and field sampling of soil solution indicate that denitrlfication probably minimizes nitrate loss from saturated soils during frequent winter to spring storm periods.

\section{INTRODUCTION}

Coast Range forests in Oregon and Washington, U.S.A., are characterized by extensively managed stands of Douglas fir mixed with hardwoods growing in a wet-winter and dry-summer climate. Often after logging, a nitrogenfixing hardwood, red alder (Alnus rubra (Bong.)), forms dense thickets that exclude Douglas fir regeneration. Soils under alder commonly accumulate organic nitrogen in excess of $20000 \mathrm{~kg} / \mathrm{ha}$ (Newton et al., 1968; Franklin et al., 1968), four times that reported for soils on Watershed \#2 in the widely publicized Hubbard Brook Ecosystem Study (Likens et al., 1970). If this large nitrogen capital were mineralized and leached into drainage waters, as occurred in New Hampshire, U.S.A., resulting in a 56-fold increase in nitrate, soil productivity could diminish and toxic concentrations of nitrate might appear in stream waters.

\footnotetext{
*Paper 1044 from the Forest Research Laboratory, Oregon State University, Corvallis, Oregon, U.S.A.

**Present address: USDA Forest Service, Southern Forest Experiment Station, Devall Street, Auburn University, AL 36849, U.S.A.
} 
Clearcutting, prescribed burning, and aerial herbicide applications are standard procedures for controlling hardwoods on the more intensively managed timber lands in the Coast Range. Until the Environmental Protection Agency's emergency Suspension in February 1579, ester formulations of 2,4,5-T were often applied aerially for hardwood control. This research was designed to determine the effects of these cultural treatments on future land productivity and water quality.

Nutrient release and nitrogen mineralization on alderdominated lands were examined by: (1) monitoring disturbed and undisturbed watersheds; (2) analyzing soil solution from cleared versus vegetated plots; and (3) quantifying through incubation studies nitrate generation under varying soil conditions. The generation and leaching of anions, principally nitrate and bicarbonate, were primarily studied, since these negatively charged nutrients drive any leaching phenomena. They are not bound tightly by soils and must carry an equal charge of cations $\left(\mathrm{Ca}^{2+}, \mathrm{Mg}^{2+}, \mathrm{K}^{+}, \mathrm{Na}^{+}\right)$as they move through the soil into the stream water.

\section{THE STUDY REGION}

Field studies were conducted at approximately $44^{\circ} 30^{\prime} \mathrm{N}$ latitude and $124^{\circ} \mathrm{W}$ longitude in Oregon's Coast Range. Soils can be as much as $4 \mathrm{~m}$ deep, on gentle slopes and bench tops, while on steep slopes they often consist of only an organic layer over stones. Thus, moisture retention and drainage rates of upland catchments vary greatly due to soil depth and slope. Much of the region is dominated geologically by marine-deposited sandstones.

Because of cracks in the sedimentary strata, watersheds in the region are probably not watertight. Since the constancy of surface-water chemistry after disturbance was the criterion for judging impact severity, not a nutrient budget approach, this lack of watertightness was of little importance to the study.

Rapid geologic processes are common in the Coast Range due to heavy winter precipitation (Z0O-270 $\mathrm{cm} /$ year), mild temperatures (monthly means from 4 to $20^{\circ} \mathrm{C}$ ), and the susceptibility of the sedimentary strata to weathering. Mountain erosion and landform dynamics are characterized by frequent slumps and rapid surface creep on slopes up to 45". Thus, stream channels and upland watersheds described in this study have been strongly influenced by such mass movements of soil and rocks. Slumps strongly influence hydrologic pathways by impeding and thus impounding subsurface drainage. This is evident by the presence of small ponds on many benches during the winter rainy season. 


\section{FIELD STUDIES}

\section{Watershed monitoring}

There were three experimental locations in red alder/Douglas fir forests:

(a) Siletz Creek

(b) Drift Creek and

(c) Brush Creek,

the locations being $7,3.2$ and $10 \mathrm{~km}$ from the Pacific Ocean, respectively. At each location minicatchments from 1.2 to 29.1 ha in size with perennial streams, like aspects and forest types were studied:

(a) Siletz Creek (S) - two catchments, the controls (C), remained untreated (SC1 and SC2), while two others (ST1 and ST2) were sprayed with herbicide so as to control red alder, while Douglas fir was clearcut harvested. The herbicide applied to all treated watersheds was either a mixture of 2,4-D and $2,4,5-\mathrm{T}$ or 2,4,5-T alone, at rates from 2.2 to $4.4 \mathrm{~kg}$ acid equivalents/ ha. Douglas fir seedlings were planted on study watersheds after primary treatments were completed.

(b) Drift Creek (D) -two catchments (DC1 and DC2) served as controls, while both red alder and Douglar fii were clearcut on DT1 and DT2 with fir logs being extracted and the catchments herbicide treated and prescribe burned.

(C) Brush Creek (B) - six catchments. BC1 and BC2 were untreated. On BT1 and BT2 broadcast spraying of herbicides eliminated alder and two other spray applications, during stream sampling, reduced shrub competition. A south-oriented watershed, BT3, was clearcut harvested and herbicide sprayed on the interior $66 \%$. All other study catchments were either northor west-facing. BT4 was a slow draining catchment that was herbicide sprayed and clearcut harvested, with fir logs being extracted and alder logs left on the ground and across the stream channel. Other adjacent catchments were sampled at Brush Creek. Soils on all watersheds were haplumbrepts and total nitrogen in the upper $15 \mathrm{~cm}$ was $0.25-0.60 \%, \mathrm{C}: \mathrm{N}$ ratios ranged from 11 to $19: 1$, and $\mathrm{pH}$ was 4.4 to 5.2 .

Stream water sampling began in September, immediately after catchments were initially treated and just before the beginning of the winter rainy season. Two-liter samples were collected approximately every 2 weeks, sealed after collection and stored at $3^{\circ} \mathrm{C}$ until analyzed. Stream discharge was measured when sampling using weirs (discharge $<0.5 \mathrm{ft}^{3} / \mathrm{s}\left(0.14 \mathrm{~m}^{3} / \mathrm{s}\right)$ ) or a current meter during peak flows. Discharge was measured primarily to compare nutrient concentrations with flow fluctuations but also to estimate nutrient loss relative to treatment. Of the two rainy seasons sampled, precipitation was above average in the winter of 1971-1972 and well below average in 1972-1973, providing contrasting conditions to observe watershed responses. 
Standard procedures for determining ion concentrations in stream water and soil solution were followed (American Public Health Association, 1971). Nitrate analyses were by the brucine method and specific conductance was determined for samples placed in a water bath at $25^{\circ} \mathrm{C}$ with a conductivity cell which measured $\boldsymbol{\mu}$ mhos $/ \mathbf{c m}$. Bicarbonate analyses were initiated within 9 months using a potentiometric titration with a weak acid to an end-point of $4.5 \mathrm{pH}$. Specific conductance and bicarbonate analyses were performed most frequently within $12 \mathrm{~h}$ of collection. Selected samples were analyzed for chloride by the argentometric method. Concentrations of the prevalent cations $\left(\mathrm{Ca}^{2+}, \mathrm{Mg}^{2+}, \mathrm{Na}^{+}\right.$, and $\left.\mathrm{K}^{+}\right)$were determined using standard atomic absorption techniques for combined samples of stream water, grouped by seasons.

Specific conductance $(\mu \mathrm{mhos} / \mathrm{cm})$ was used to estimate total anion concentrations (meq/l) in stream waters (Ponnamperuma et al., 1966; Tanji and Biggar, 1972). Summed anion concentrations, $\mathrm{Y},\left(\mathrm{HCO}_{3}^{-}+\mathrm{NO}_{3}^{-}+\mathrm{Cl}^{\prime}+\right.$ $\mathrm{SO}_{4}^{2-}+\mathrm{PO}_{4}^{3-}$ ), and specific conductance, $K$, were regressed using data from 46 complete analyses of stream water draining the study region. The least squares fit was $\mathrm{Y}=0.00888 \mathrm{~K}$, with $r^{2}=0.92$. To verify this equation for our specific upland streams, summed concentrations of nitrate and bicarbonate were regressed against specific conductance using 333 analyses from this study. The resulting equation was $\mathrm{Y}=-0.1988+0.00891 \mathrm{~K}$, with $r^{2}=\mathbf{0 . 8 6}$. Absence of chloride concentrations and minor anions accounts for the negative y-intercept. Chloride data from this study and the Alsea River Basin Study (Brown et al., 1973) ranged consistently between 0.1 and 0.2 meq/l, as predicted by the regression. Slope coefficients of the two regressions were not statistically different; consequently, the factor of 0.00888 was used to estimate total anions from specific conductance readings.

Treatment and watershed differences were tested with one- and two-way analyses of variance. These tests used sample concentrations confined within seasons of the water-year without weighting for discharge. Common collection dates and grouping by periods of like storm-events eliminated the need for weighting.

\section{Soil solution lysimeter study}

Soil solution from cleared and vegetated plots was extracted from the BT3 watershed at three depths to investigate the influence of downward percolation and live alder cover on anion generation and leaching. Tension-cup lysimeters were installed at depths of 10,65 , and $130 \mathrm{~cm}$ on two sites, about $150 \mathrm{~m}$ apart, which differed principally in the presence or absence of 80year-old alder. On the cleared plot, herbaceous regrowth was controlled by hand weeding. Both locations were on level toes of 11" slopes with similar soil profiles. Organic matter and most fine roots occurred between 0 to $45 \mathrm{~cm}$, although structural roots penetrated into the water-permeable colluvium. Lysimeters consisted of ceramic cups $6 \mathrm{~cm}$ in diameter attached to 
polyvinylchloride pipe*. Assembly and installation were according to Parizek and Lane (1970), and recommendations by Hansen and Harris (1975) were followed to minimize sampling bias. Soil solutions were collected weekly using a 0.8 atm vacuum, which is slightly greater than an estimated field capacity tension of $-0.2 \mathrm{~atm}$.

\section{Watershed results}

The most striking observation from the control watershed data is the relative constancy in both total and component anion concentrations throughout the water year. Even though discharge varies 100 -fold from rainy season stormflows $\left(4.4 \mathrm{ft}^{3} / \mathrm{s}\left(0.12 \mathrm{~m}^{3} / \mathrm{s}\right)\right)$ to summer base-flows $\left(0.004 \mathrm{ft}^{3} / \mathrm{s} \quad(0.000113\right.$ $\left.\mathrm{m}^{3} / \mathrm{s}\right)$ ), the concentrations of total anions did not vary more than $\pm 20 \%$. Thus, during frequent winter storms, organisms in these streams are not subjected to large fluctuations in nutrient concentrations. This can be seen in the presentation of the watershed data in Figs. 1,2, and 3. This presentation format allows a holistic look at watershed behavior as compared to separate figures showing concentrations in parts per million. The hydrographs show the absence of summer storms which minimizes the leaching of soil nutrients during the growing season.

Excessive nutrient losses did not occur even after complete clearcutting, herbicide spraying, and prescribed burning. In fact, severely treated watersheds behaved essentially like completely forested watersheds with only minor deviations. After clearcutting (Figs. 1 and 2) summer bicarbonate con-

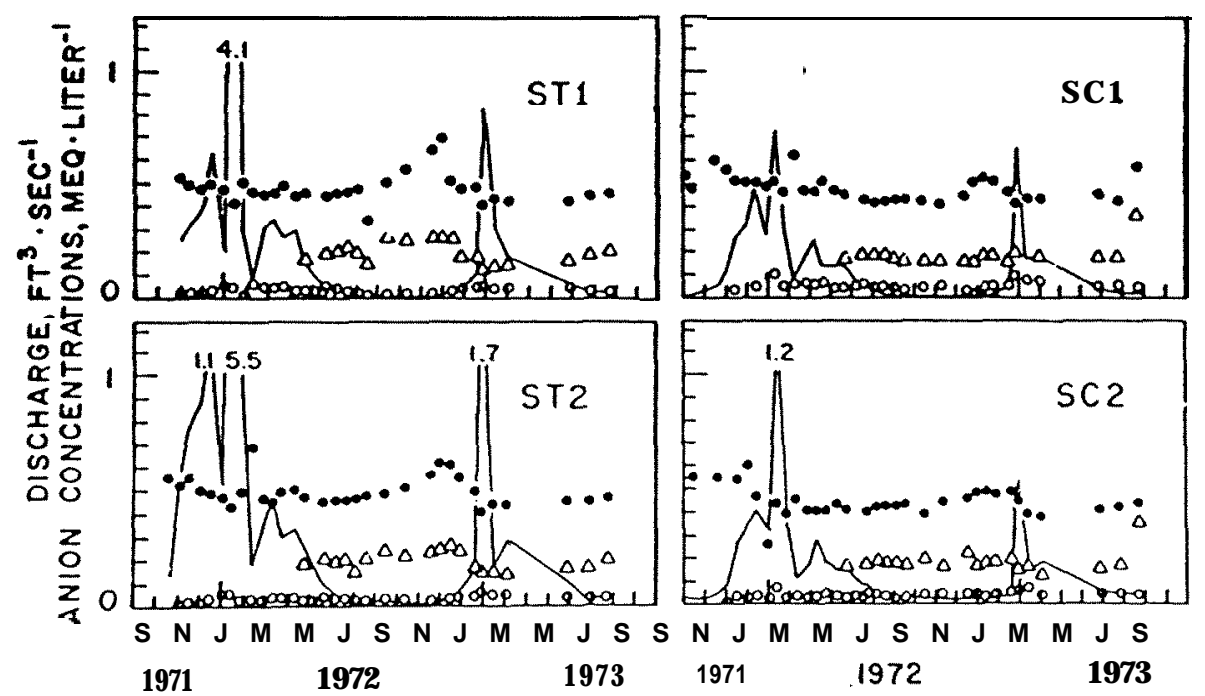

Fig. 1. The seasonally changing discharges $(-)$ and concentrations of $\mathrm{NO},(\mathrm{O}), \mathrm{HCO},+$ NO, $(\Delta)$, and total anions (•) from two untreated control catchments (SC1 and SC2) and two treated catchments (ST1 and ST2) at Siletz Creek. At ST1 and ST2 the mixed stand of red aider/D ouglas fir was sprayed with herbicide to minimize alder regrowth while the fir was clearcut prior to replanting with Douglas fir.

*Soilmoisture Equipment Corporation, Santa Barbara, CA, U.S.A. 


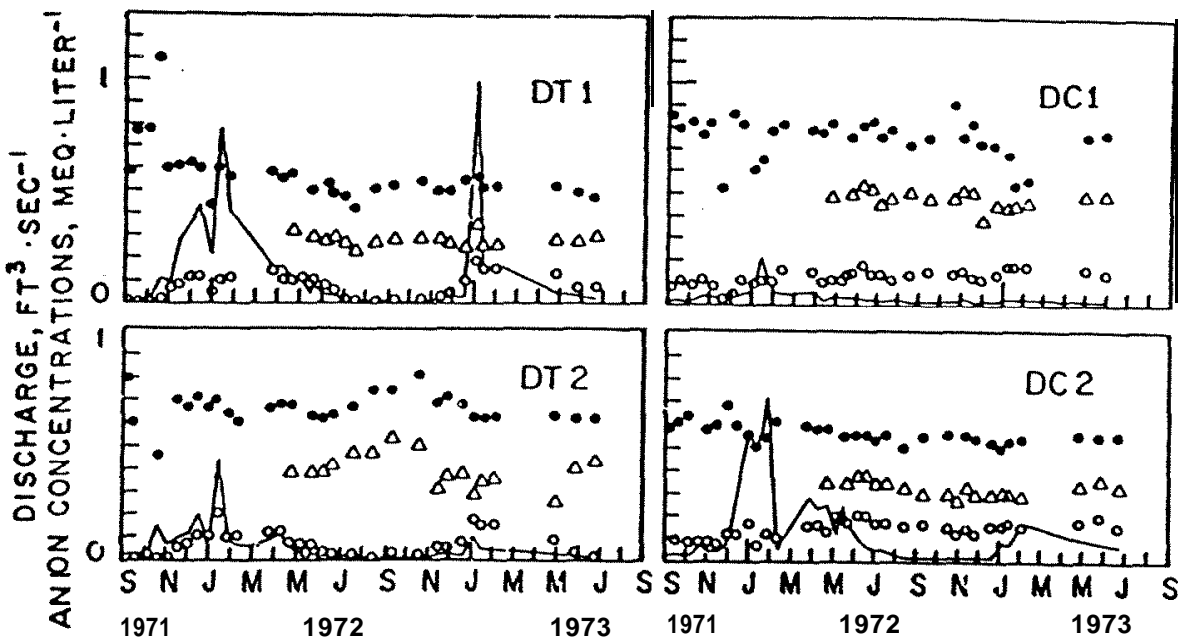

Fig. 2. The seasonally changing discharges (-) and concentrations of $\mathrm{NO},(\mathrm{O}) \mathrm{HCO},+\mathrm{NO}$, $(\Delta)$ and total anions (•) from two untreated catchments (DC1 and DC2) at D rift Creek; on DT1 and DT 2 the mixed stand of red alder/D ouglas fir was clearcut, herbicide sprayed, and burned before replanting with Douglas fir.

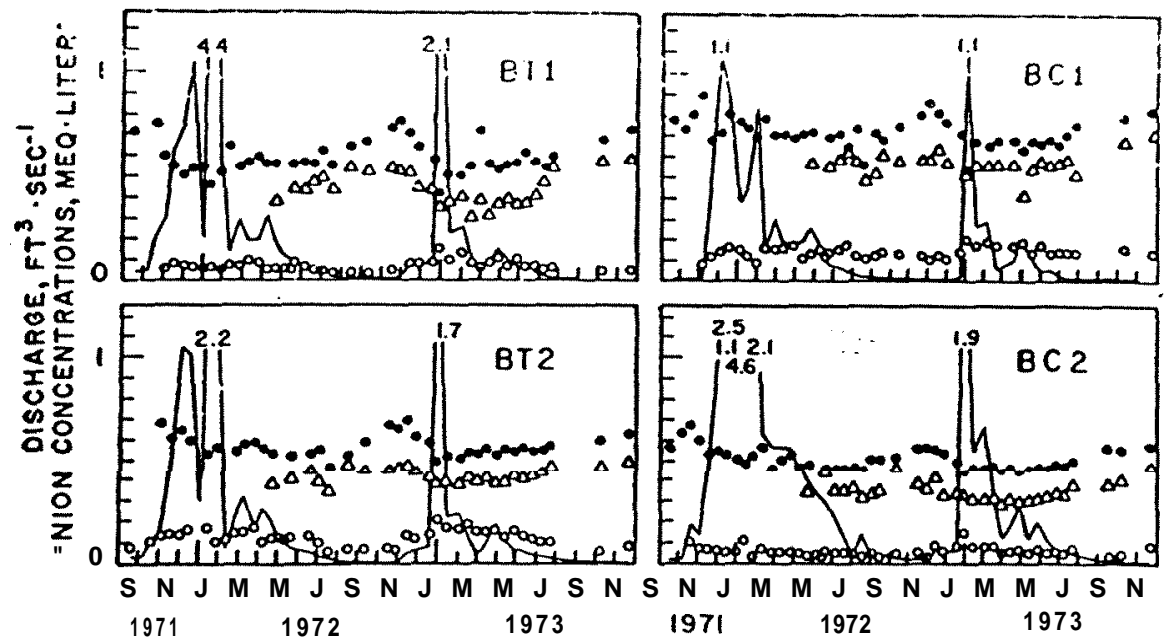

Fig. 3. The seasonally changing discharge $(-)$ and concentrations of $\mathrm{NO},(0), \mathrm{HCO},+$ NO, $(\triangle)$, and total anions $(\bullet)$ from two untreated control (BC1 and BC2) catchments and two treakd catchments (BT1 and BT2) at Brush Creek. At BT1 and BT2 the red alder stands were eliminated using herbicides prior to planting with Douglas fir, followed by herbicide applications to reduce shrubs.

centrations were greater $(\alpha=0.05)$ compared to control watersheds, while herbicide treatments alone (Fig. 3) did not significantly elevate bicarbonate. The clearcut watershed BT3, had the most pronounced increase in summer bicarbonate (Fig. 4). A three-fold rise during the two summers following clearcutting and herbicide treatments was the most pronounced response due to treatment of the eight disturbed catchments being monitored.

Variables that increase bicarbonate during low flows were studied further 


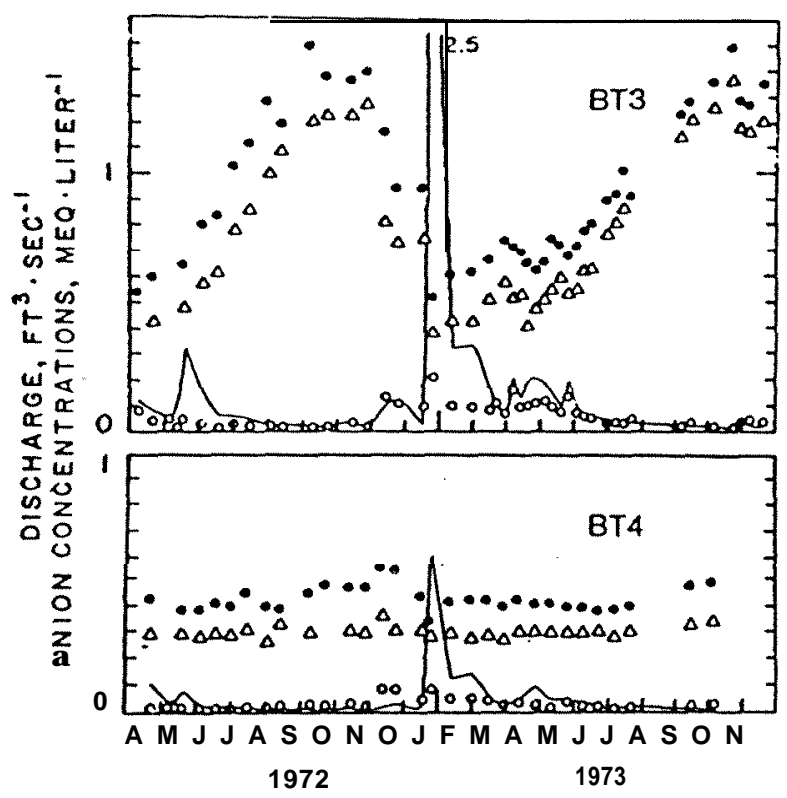

Fig. 4. The seasonally changing discharge (-) and concentrations of NO, (o), HCO, + NO, (A) and total anions (•) from two treated catchments, BT3 and BT4. BT3 was $60 \%$ clearcut (interior portion), and the logged area was treated with herbicides prior to -planting with Douglas fir. BT4 was clearcul and sprayed with herbicide and planted.

\section{TABLE I}

Mean bicarbonate concentrations (ppm) in summer base-flow from watersheds with contrasting exposures at Brush Creek

\begin{tabular}{|c|c|c|c|c|c|c|}
\hline \multirow{3}{*}{$\begin{array}{l}\text { Sample } \\
\text { period (1973) }\end{array}$} & \multicolumn{3}{|l|}{ south } & \multicolumn{3}{|c|}{ North } \\
\hline & \multirow{2}{*}{$\frac{\text { Clearcut }}{\text { BT3 }}$} & \multicolumn{2}{|c|}{ Undisturbed $^{\mathrm{a}}$} & \multicolumn{2}{|c|}{ : Herbicide } & \multirow{2}{*}{$\frac{\text { Undisturbed }}{\text { BC1 B C } 2}$} \\
\hline & & 1 & 2 & BT1 & BT2 & \\
\hline \multirow{3}{*}{$\begin{array}{l}15 \text { June-9 August } \\
9 \text { August-15 September } \\
15 \text { September-14 October }\end{array}$} & 1.32 & 0.68 & 0.38 & 0.30 & 0.22 & 0.230 .19 \\
\hline & 1.80 & 0.48 & 0.34 & 0.32 & 0.26 & 0.310 .21 \\
\hline & 1.76 & 0.44 & 0.34 & 0.32 & 0.26 & 0.350 .23 \\
\hline
\end{tabular}

Unnamed watersheds adjacent to BT3.

at the Brush Creek site. Additional samples were collected from BT3 and two adjacent watersheds during the second summer after BT3 was treated. Table I shows that on the same geological formation, south-oriented watersheds had greater bicarbonate concentrations $(\alpha=0.01)$ than north-facing ones, regardless of treatment. On 30" slopes, yearly solar insolation is 2.5 times greater for southern aspects than for northern aspects at this latitude (Buffo et al., 1972), which would result in warmer soil temperatures. Higher temperatures yield increased concentrations of bicarbonate in soil solutions 
according to McColl (1972). Thus, drainage water concentrations were more elevated on BT3, which was exposed to the most insolation due to a southern aspect and clearcutting.

To estimate the possible duration of abnormally high bicarbonate concentrations after clear-cutting treatments, additional stream samples were collected from a clearcut watershed in the Alsea River Basin Study (Brown et al., 1973) having a southern aspect. There, too, bicarbonate was initially increased as indicated by elevated conductance readings. On resampling the 6-year-old clearcut, we found bicarbonate during summer months equal to nearby undisturbed watersheds. This suggests that elevated bicarbonate concentrations from south-facing clearcuts do not last more than six summers.

Nitrate concentrations were significantly less $(\alpha=0.01)$ on the treated watersheds during summer compared to winter months, corresponding to the rise in bicarbonate. The Siletz site differed significantly from the other two study sites $(\alpha=0.01)$, but nitrate depression was a common response for all treatments. Thus, on north- and east-facing watersheds during low-flow summer periods the equalizing result of a bicarbonate rise and nitrate depression yielded no detectable increase in total anion concentrations that could be attributed to treatment.

Catchments at Brush Creek were also sampled further to determine the influence of slope on nitrate concentrations. It had been observed that watersheds having level or depressioned benches, restricted drainage, yielded lower nitrate concentrations, e.g., BT'1, BT4, BC2 and the Siletz catchments. Areas of high moisture retention and saturated soils have been shown to create anaerobic conditions which theoretically fosters denitrification (Broadbent and Clark, 1965). In the current study, nitrate concentrations were greater $(\alpha=0.01)$ in waters draining steep landforms $(>40$ " slopes) than in essentially level poorly drained ones (Table II, Fig. 5). Evidence suggesting denitrification will also be presented in the incubation and lysimeter studies.

Cation concentrations (Table III) were not affected by treatment $(\mathrm{a}=0.01)$ when the 12 watersheds were compared. At Brush Creek, calcium

\section{TABLE II}

Effects of watershed drainage rates on nitrate concentrations (ppm)

\begin{tabular}{|c|c|c|c|c|}
\hline \multirow{2}{*}{$\begin{array}{l}\text { Sample } \\
\text { date (1973) }\end{array}$} & \multicolumn{2}{|l|}{ Level } & \multicolumn{2}{|c|}{ Steep } \\
\hline & BT 4 & $\overline{B C 3^{a}}$ & $\overline{\text { BT } 3}$ & $\mathrm{BC} 1$ \\
\hline $\begin{array}{l}3 \text { September } \\
23 \text { March } \\
6 \text { April } \\
20 \text { April } \\
4 \text { May }\end{array}$ & $\begin{array}{l}1.8 \\
1.3 \\
0.4 \\
1.8 \\
0.9\end{array}$ & $\begin{array}{l}2.2 \\
2.9 \\
1.3 \\
3.1 \\
2.2\end{array}$ & $\begin{array}{l}5.7 \\
7.1 \\
7.5 \\
\text { a.4 } \\
3.5\end{array}$ & $\begin{array}{r}10.2 \\
11.1 \\
a .4 \\
10.2 \\
9.0\end{array}$ \\
\hline
\end{tabular}

${ }^{a}$ Level bench adjacent to BT 3 and BT4, an undisturbed catchment. 


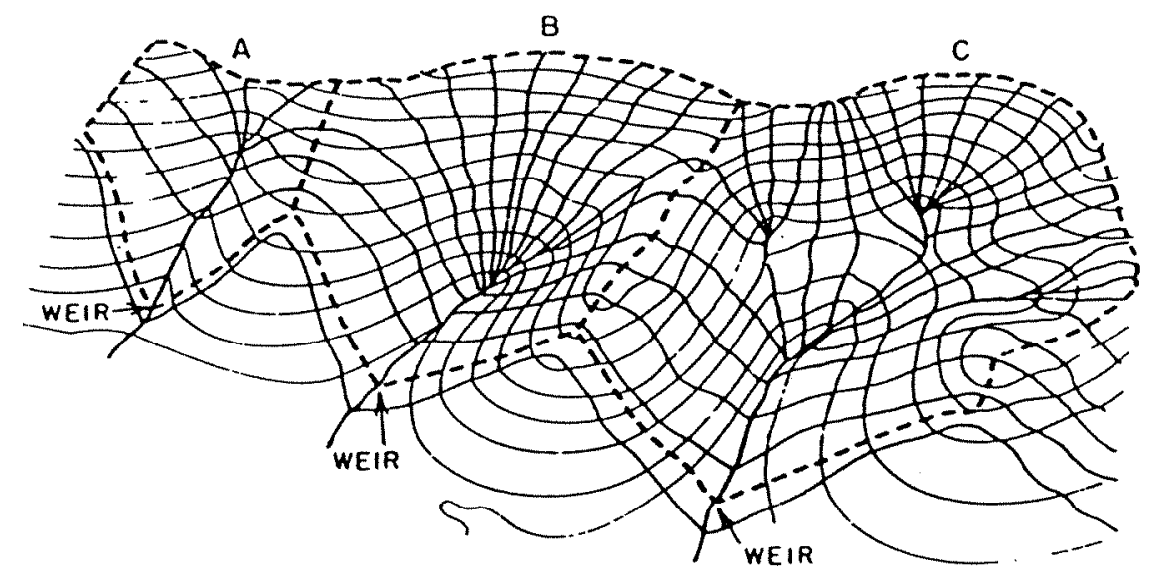

Fig. 5. The physiognomy of watersheds common to the Tyee Sandstone Formation. Examples $\mathrm{A}$ and $\mathrm{B}$ drain more rapidly than example $\mathrm{C}$, which drains slowly because of accumulations of subsurface drainage on benches.

TABLE III

Yearlyaverage concentrations (ppm) of cations and anions and annual nitrate loss $(\mathrm{kg} / \mathrm{ha})$

\begin{tabular}{|c|c|c|c|c|c|c|c|}
\hline \multirow{2}{*}{$\begin{array}{l}\text { Treatment } \\
\text { and } \\
\text { watershed }\end{array}$} & \multicolumn{4}{|c|}{ Cations } & \multicolumn{2}{|c|}{ Anions } & \multirow{2}{*}{$\begin{array}{l}\text { Annual } \\
\text { NO,-N } \\
\text { loss }\end{array}$} \\
\hline & $\begin{array}{l}- \\
\mathrm{N}_{2}\end{array}$ & $\mathrm{Ca}^{-}$ & $-\overline{M_{G}}$ & $\mathrm{~K}^{-}$ & $\mathrm{HCO}$ & $\mathrm{NO}$ & \\
\hline \multicolumn{8}{|c|}{$\begin{array}{l}\text { Siletz Creek site } \\
\text { Herbicide and clearcut }\end{array}$} \\
\hline ST1 & 11.3 & 1.6 & 1.2 & 0.8 & 9.8 & 2.2 & 12 \\
\hline $\begin{array}{r}\text { ST2 } \\
\text { Control }\end{array}$ & 12.2 & 1.6 & 1.2 & 1.2 & 9.8 & 1.8 & 15 \\
\hline $\mathrm{SC} 1$ & 11.7 & 1.6 & 1.0 & 0.8 & 7.9 & 3.5 & 17 \\
\hline $\mathrm{SC} 2$ & 10.6 & 1.6 & 1.0 & 0.8 & 8.5 & 1.8 & 13 \\
\hline \multirow{2}{*}{\multicolumn{8}{|c|}{$\begin{array}{l}\text { Drift Creek site } \\
\text { Clearcut, herbicide, and slash burning }\end{array}$}} \\
\hline & & & & & & & \\
\hline DT1. & 12.4 & 2.0 & 1.9 & 1.6 & 12.2 & 4.9 & 24 \\
\hline $\begin{array}{r}\text { DT2 } \\
\text { Control }\end{array}$ & 14.5 & 3.2 & 2.2 & 1.6 & 18.9 & 4.0 & 47 \\
\hline DC1 & 17.3 & 3.3 & 2.4 & 1.2 & 19.5 & 7.1 & 41 \\
\hline $\mathrm{DC} 2$ & 12.2 & 2.0 & 1.9 & 1.2 & 9.1 & 8.9 & 27 \\
\hline \multicolumn{8}{|c|}{$\begin{array}{l}\text { Brush Creek site } \\
\text { Herbicide }\end{array}$} \\
\hline BT1 & 12.2 & 3.6 & 2.2 & 1.2 & 22.6 & 4.0 & 27 \\
\hline $\begin{array}{r}\text { BT2 } \\
\text { Control }\end{array}$ & 11.5 & 3.6 & 2.2 & 1.2 & 17.7 & 7.5 & 67 \\
\hline $\mathrm{BC} 1$ & 13.3 & 4.8 & 2.9 & 0.8 & 25.6 & 8.5 & 74 \\
\hline $\mathrm{BC} 2$ & 11.3 & 2.8 & 1.7 & 1.2 & 17.1 & 3.5 & 17 \\
\hline \multicolumn{8}{|c|}{ Partial clearcut and herbicide } \\
\hline BT3 & 14.7 & 6.0 & 4.1 & 1.6 & 43.9 & 4.0 & 21 \\
\hline BT4 & 8.7 & 2.4 & 1.7 & 1.6 & 15.9 & 1.8 & 5 \\
\hline
\end{tabular}


and magnesium were more concentrated in waters draining BT3 $(\alpha=0.01)$, but this change cannot be attributed to treatment because there were no control watersheds of similar aspect for accurate comparisons. Yearly loss estimates for the anions were calculated for each watershed, No increases due to treatment were indicated. Yearly nitrogen losses due to nitrate migration are presented in Table III. The highest yearly losses came from the steeper watersheds (Fig. 5), regardless of treatment. This positive relationship between steepness and losses of both nitrate and total anions is evident in Figs. 2 and 3, showing greater concentrations from the steeper catchments DT2, DC1, and BT2 and BC1. The three-fold increase in bicarbonate concentrations on BT3 occurred during the period of minimum discharge and had no effect on total anion loss for the year.

\section{Lysimeter results}

Nitrate concentrations decreased in soil solutions at lower depths $(\alpha=0.01)$ and were least in stream water (Table IV), during spring to summer collections. A likely period for nitrate leaching losses. Nitrate concentrations did not differ significantly between clearcut and unharvested sites. Declines in concentrations as soil solutions percolate deeper into saturated or near-saturated zones are most likely due to denitrification. Saturated conditions were indicated at the lower soil depths by taking timed extractions after normal collections. Decreasing nitrate wrih increasing depth had been documented in saturated lower profiles by Meek et al. $(1969,1970)$.

\section{TABLE IV}

\begin{tabular}{|c|c|c|c|c|}
\hline $\begin{array}{l}\text { Location } \\
\text { and depth }\end{array}$ & $\begin{array}{l}\mathrm{NO}_{3} \\
\text { (ppm) }\end{array}$ & $\begin{array}{l}\mathrm{HCO}_{3} \\
\text { (ppm) }\end{array}$ & $\begin{array}{l}\text { specific } \\
\text { conductivity } \\
\text { ( } \mu \text { mhos } / \mathrm{cm})\end{array}$ & $\mathrm{pH}$ \\
\hline \multicolumn{5}{|l|}{ Alder stand } \\
\hline Throughfall & 1.3 & 10.3 & 57 & 5.9 \\
\hline $10 \mathrm{~cm}$ & 38.1 & 26.0 & 162 & 7.2 \\
\hline $65 \mathrm{~cm}$ & 28.3 & 34.3 & 166 & 7.0 \\
\hline $130 \mathrm{~cm}$ & 19.0 & 79.1 & 190 & 6.8 \\
\hline \multicolumn{5}{|l|}{ Clearcutting } \\
\hline Rainwater & 0.4 & 5.5 & 26 & 6.0 \\
\hline $10 \mathrm{~cm}$ & 26.6 & 42.5 & 150 & 7.4 \\
\hline $65 \mathrm{~cm}$ & 36.3 & 38.6 & 151 & 6.7 \\
\hline $130 \mathrm{~cm}$ & 8.9 & 75.2 & 166 & 6.7 \\
\hline Stream Water & 4.4 & 36.4 & 92 & 7.3 \\
\hline
\end{tabular}


Bicarbonate increased $(\alpha=0.01)$ with depth, presumably because of increased $\mathrm{CO}_{2}$ partial pressures (Boynton and Compton, 1944; McColl and Cole, 1968). The compensating behavior of nitrate and bicarbonate is also demonstrated in the lysimetric sampling as in stream waters. Balancing shifts in the concentrations of both produced a slight increase in specific conductance at the $130 \mathrm{~cm}$ depth but no significant change at the different depths. An indication that total anion loss was not increased.

\section{LABORATORY STUDY}

An incubation study was performed to estimate the leachable nitrogen generated in surface soils under local environmental conditions. A factorial design with duplicate blocks was used, testing the combinations of

(a) four moisture contents; $0,0.3,2$ and 15 atm tension and,

(b) four temperatures; $7,14,21$, and $28^{\circ} \mathrm{C}$.

Duplicate sets of soils were withdrawn from the incubation chambers at 15 , 30 , and 45 days, to gain a time dimension.

In the spring, soil samples were collected $(\mathrm{O}-15 \mathrm{~cm}$ depth) from five alder stands within the study region and equal portions were combined into one sample. A separate, uncombined sample was collected from the BT3 watershed to compare with soils collected at the same location the previous fall. Soils were air dried and screened to less than $4 \mathrm{~mm}$. Appropriate amounts of distilled water were added to $43 \mathrm{~g}$ (oven-dry weight) incubation sainples to yield the four moisture contents, with moisture ieveis restored every 14 days, Styrofoam cups with lids with $1 \mathrm{~mm}$ holes served as incubation containers. After incubation, both extractable ammonium and nitrate nitrogen were determined using one $40 \mathrm{~g}$ sample via Bremner and Kenney's technique (1966).

\section{Nitrogen mineralization}

The fact that nitrification is rapid in well drained alder soils at high temperatures is shown by the similarity with the ammonification response surfaces at 15, 30, and 45 days (Fig. 6). Thus, there is a real potential for severe nitrate loss into stream waters. Saturated soils resulted either in extremely slow rates of mineralization or in ammonium immobilization and denitrification (below zero). Denitrification, rather than nitrate immobilization by the microbial populations, is assumed because of 75 years of documentation of this phenomenon at saturated soil conditions (Broadbent and Clark, 1965). In saturated alder soils, denitrification was evident at $14^{\circ} \mathrm{C}$ but not at $7^{\circ} \mathrm{C}$. Harmsen and Kolenbrander (1965) concur that at temperatures below $10^{\circ} \mathrm{C}$ denitrification is not significant.

In Fig. 7 soil temperature and moisture regimes are shown for the upper $10 \mathrm{~cm}$ on a southern aspect at the lysimeter installation sites. Winter and spring moisture contents are above field capacity $(0.3 \mathrm{~atm})$ and almost at 


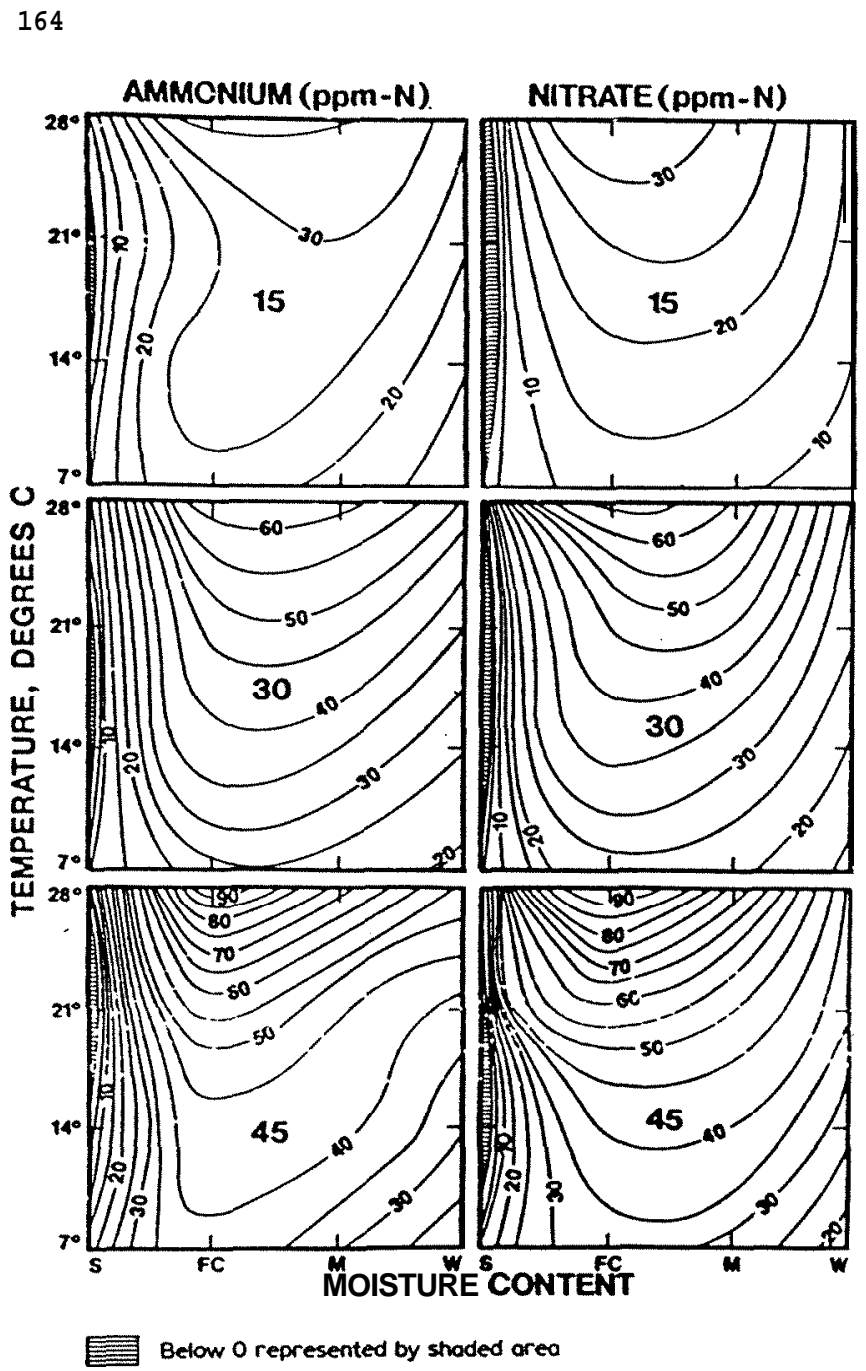

Fig. 6. Ammonium and nitrate production in incubated red alder soils after 15, 30, and 45 days.

saturation in the upper $10 \mathrm{~cm}$, which indicates saturation at lower profile depths. Thus under alder stands, ammonification in the surface soil would be slow during the rainy winter and spring months, while nitrification would be minimal, going to denitrification at lower depths. In the clearcutting, surface conditions (Fig. 7) would suggest higher rates of nitrate production, with the possibility of leaching taking place during wet springs before nitrogen uptake commences. This was not found in either stream water or lysimetric sampling. Saturated zones in the lower profile and on benched watersheds would result in denitrification.

On newly harvested watersheds that are treated with herbicides, such as BT3, nitrogen uptake and immobilization by vegetation is suppressed. This 


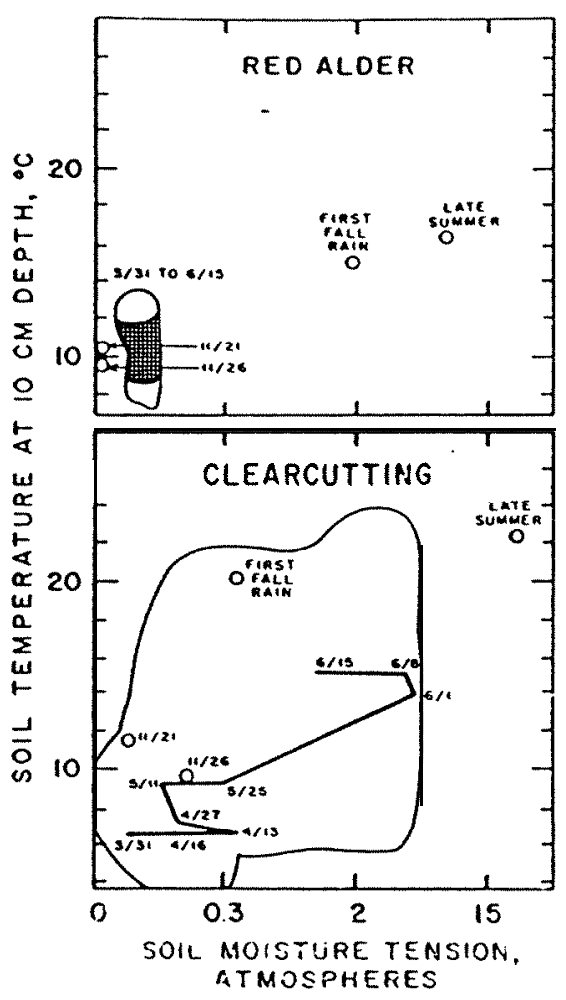

Fig. 7. Temperature-moisture regimes of surface soil on a south aspect under a red alder stand and on a clearcuttmg. Shaded area or line indicate daily means; enclosed areas, show diurnal fluctuations.

TABLE V

Ammonium and nitrate nitrogen production (ppm $N$ ) in soils collected from the same red alder stand in May and October and incubated at field capacity $(0.03$ atm) and 7 " and $21^{\circ} \mathrm{C}$ for 45 days

\begin{tabular}{|c|c|c|c|c|}
\hline \multirow{2}{*}{$\begin{array}{l}\text { Collection } \\
\text { month }\end{array}$} & \multicolumn{2}{|l|}{$\underline{7^{\circ} \mathrm{C}}$} & \multicolumn{2}{|l|}{$21^{\circ} \mathrm{C}$} \\
\hline & $\mathrm{NH}_{4}^{+}$ & No; & $\mathrm{NH}_{4}^{+}$ & NO; \\
\hline May & 117 & 72 & 177 & 171 \\
\hline October & 34 & 31 & 64 & 76 \\
\hline
\end{tabular}

appears to present a possible time for nitrate loss during initial fall rains before soil temperatures decrease and soil saturation occurs. However, such losses were not evident during stream water monitoring. Incubated soils collected in October had ammonification and nitrification rates that were $30 \%$ and $50 \%$ less than for soils collected in May (Table V). These rates suggest that less soluble $\mathrm{N}$ is present for leaching during heavy fall precipitation. Mineralization rates under alder apparently can change with season, thus influencing organic- $\mathrm{N}$ retention. 


\section{SUMMARY}

Forest-soil systems in the Coast Range of Oregon with partial or total red alder cover are relatively stable after management treatments of clearcut harvesting, slash burning, and herbicide spraying. Nutrient loss from soils in this dry-summer and wet-winter region appear to be more a function of climate and local topographic influences on insolation exposure, drainage patterns, and resident time of subsurface flow, rather than the types of disturbances investigated. A natural balance between nitrate and bicarbonate anions in the nutrient leaching system promotes on-site retention of macronutrients. Denitrification appears to reduce nitrate leaching from saturated soils, often found during winter storms at lower profile depths and on benches common to upland catchments. Denitrification represents a possible route for gaseous nitrogen loss and further studies are needed that can monitor $\mathrm{N}_{2} \mathrm{O}$ and $\mathrm{N}_{2}$ evolution in the field to confirm this mechanism.

\section{REFERENCES}

American Public Health Association, 1971. Standard Methods for the Analysis of Water and Wastewater, 13th edn. Washington, DC, $874 \mathrm{pp}$.

Boynton, D. and Compton, O.C., 1944. Normal seasonal changes of oxygen and carbon dioxide percentages in gas from the iarger pores of three orchard soils. Soil Sci., 57: $107--117$.

Bremuer, J.M. and Kenney, D.R., 1966. Determination of isotope-ratio aralysis of different forms of nitrogen in soils. Soil Sci. Soc. Am. Proc., 30: 577-582.

Broadbent, F.E. and Clark, F.E., 1965. Denitrification. In: W.V. Bartholomew and F.E. Clark (Editors), Soil Nitrogen. Am. Soc. Agron. Ser. 10. Madison, WI, pp. 344-459.

Brown, G.W., Gahler, A.R. and Marston, R.B., 1973. Nutrient losses after clearcut logging and slash burning in Oregon Coast Range. Water Resour. Res., 9: 1450-1453.

Buffo, J., Fritschen, L. and Murphy, J., 1972. Direct Solar Radiation on Various Slopes from 0 to 60 degrees North Latitude. USDA For. Serv., Res. Pap. PNW-142, 74 pp.

Franklin, J.F., Dyrness, C.T., Moore, D.G. and Tarrant, R.F., 1968. Chemical soil properties under coastal Oregon stands of alder and conifers. In: JM. Trappe, J.F. Franklin, R.F. Tarrant, and GM. Hansen (Editors), Biology of Alder. USDA For. Serv., Pac. Northwest For. Range Exp. Stn., Portland, OR, pp. 73-84.

Hansen, E.A. and Harris, A.R., 1975. Validity of soil-water samples collected with porous ceramic cups. Soil Sei. Soc. Am. Proc., 39(3):528-536.

Harmsen, G.W. and Kolenbrander, G.J., 1965. Soil inorganic nitrogen. In: W.V. Bartholomew and F.E. Clark (Editors), Soil Nitrogen. Am. Soc. Agron., Ser. 10, Madison, WI, pp. 43-92.

Likens, G.E., Bormann, F.H., Johnson, NM., Fisher, D.W. and Pierce, R.S., 1970. Effects of forest cutting and herbicide treatment on nutrient budgets in the Hubbard Brook watershed ecosystem. Ecol. Monogr., 40: 23-47.

McColl, J.G., 1972. Dynamics of ion transport during moisture flow from a Douglas fir forest floor. Soil Sci. Soc, Am. Proc., 36: 668-674.

McColl, J.G. and Cole, D.W., 1968. A mechanism of cation transport in a forest soil. Northwest Sci., 42: 134-140.

Meek, B.D., Grass, LB., and MacKenzie, A.J., 1969. Applied nitrogen loss in relation to oxygen status of soils. Soil Sci. Soc. Am. Proc., 33: 575-578. 
Meek, B.D., Grass, L.B., Willardson, LS. and MacKenzie, A.J., 1970. Nitrate transformations in a column with a controlled water table. Soil Sci. Soc. Am. Proc., 34:

235- 239.

Newton, M., El Hassan, B.A. and Zavitkovski, J., 1968. Role of red alder in western Oregon succession. In: J.M. Trappe, J.F. Franklin, R.F. Tarrant and GM. Hansen (Editors), Biology of Alder. USDA For. Serv., Pac. Northwest For. Range Exp. Stn., Portland, OR, pp. 73-84.

Parizek, RR and Lane, B.R., 1970. Soil-water sampling using pan and deep pressure vacuum lysimeters. J. Hydrol., 11: 1-21.

Ponnamperuma, F.N., Tianco, EM. and Loy, T.A., 1966. Ionic strength of the solutions of flooded soils and other aqueous solutions from specific conductance. Soil Sci., 102: 408413.

Tanji, K.K. and Biggar, J.W., 1972. Specific conductance model for natural waters and soil solutions of limited salinity levels. Water Resour. Res., 8: 145-153. 